\title{
Planning of Marketing Communication Activities in Jordanian Pharmaceutical Companies Using the Balanced Scorecard
}

\author{
Dr. Iyad A. Al-Nsour* \\ School of Media \& Communication, Al Imam Muhammad ibn Saud University, \\ Department of Advertising and Marketing Communication, Riyadh, Saudi Arabia \\ * E-mail of the corresponding author: nsour 2005@yahoo.com
}

\begin{abstract}
This study aims at exploring the effect of using the BSC perspectives on planning of marketing communication activities in Jordanian pharmaceutical companies. The BSC consists of four perspectives: financial, customers, internal processes and growth and learning. The study also aims at determining the statistical differences in the market share of Jordanian pharmaceutical according to level of using the two variables (BSC and planning of MC activities). This study is descriptive. The questionnaire is the key tool of collecting the data needed from research population. The sample size reached to 231 managers, and the cluster random sample is used. The study concludes that there is a positive statistical effect of financial perspective on planning of marketing communication activities, but the other three non-financial measures statistically failed. It finds also that there a statistical difference in the market share of pharmaceutical companies having BSC perspectives and planning the marketing communication activities. Finally, the study recommends many implications and recommendations that support BSC applications and enhance the planning of marketing communication activities in surveyed companies.
\end{abstract}

Key Words: Planning, Marketing Communication, Balanced Scorecard, pharmaceutical companies, Jordan. DOI: $10.7176 / \mathrm{NMMC} / 77-07$

\section{Introduction}

Strategic planning as a process that takes into consideration future research that aims at exploring the long run trends and issues and merging the regulatory priorities with market opportunities, thus SP has a key role in achieving the organizational objectives using the most efficient ways and resources (Caune\& Dzedons, 2009). So strategic planning is trying to understand the challenges, trends and issues that affect customers' needs precisely, and this situation will ensure the best financial results of organization and acceptable market share (Leiks, 2007). Strategic planning is the cornerstone of organizations that seeking for growth in the existing and potential markets, and forecast the future situation, thus, the strategic planning enables the organization assessing the current and future situations (Rothaermel, 2012). Strategic planning is a tool that helps the organizations doing the best and focusing on use the core capabilities to access the strategic desired position, in order to making a compatible decision between the resources and market opportunities, and the literatures noted that strategic planning is controlled efforts aims at making the right decisions to improve the current position and to maximize the future value of organization in the existing and potential markets (Cundall, 2018).

The concepts and tools of planning process are found in the early of seventies in the last century, and this happened as a reflection of economic shocks that faced the American industries in the energy sector (it was called the energy crisis), rates of inflation have increased the pressures on demand and have caused the stagnation, and also the Japanese companies were collapsed, in addition to legal problems (Johnson,Scholes \&whittington,2008). American companies have tried to react quickly with the urgent cases, for example the destroyed companies have used the simple growth method in planning of production, sales, and profits ant this method go on until the idea of strategic planning is matured, the optimal organizing of business resources to face the unexpected situations that will happened (Maleka,2014).

The concept of business strategy was introduced in 1951 when Newman noted the importance of such strategy for economic project during planning process, and in 1960s, the grounded principles of strategic planning are introduced. Andrws' work is a key engine of strategic management field, and the models of business portfolio analysis are established such as BCG matrix, GE matrix, McKenzie 7-S model, Hofer model,etc. In the late of 1980 s, Porter has presented a model aimed at analyzing the concept and strategies of competitive advantage. In 1990s, the central efficiency model and method based resources are found (Finley,1999). All of developments have changed the businesses trends and priorities, and large scale of such developments have focused on developing the organizational skills and resources as well as the managerial efficiency in resources allocation (Maleka,2014).

The strategic planning in modern organizations has large proportion and it is become integrated managerial 
process aims at developing and harmonizing among the business objectives, skills, resources and market opportunities. The strategic planning process has ability of designing the business strategies, identifying profitable products and promoting growth and sustainability in the targeted market.

Within the discussions among researchers about the indicators (PIs) that could be assessed business performance, balanced scorecard model is presented a key tool of strategic position formulation (Sordo, Orelli, Padovani\&Gardini,2012), and it is consisted of financial and non-financial measures that present a wide picture of future performance and the best possible ways to achieve it (Kaplan\&Norton,2015). This card is considered a vital tool to stimulate and to measure the performance of business units and to provide a balanced view about actual performance and future direction (Bulter et al.,1997, p.242), by presenting timely accurate information of top management, the interactive relationship between operational processes and strategic directions of organization are measured (Kaplan\&Norton,1992, p.71).

In this content, our research aims at measuring the relationship balanced scorecard and planning of marketing communication activities. The MC is one of the most important functions enable the organizations achieving the profits, enhancing competition, growing the market share and improving business image. Organizations may be failed in the market, if they are not being aware about target audiences, so it necessary to take overall market changes in the considerations. The success in designing efficient, speedy, effective and interactive communication tools, will ensure the good safe flow of information from the organization to target audience and vice versa.

\section{Research Statement:}

The field of research seems one of the most prominent economic leaders in Jordan economy. Jordan is one of the leading countries in the pharmaceutical industry among Middle East countries, and the roots of such industry back to year 1962, when Al-Hekma Company is established. In 2017, it has sales reached to $\$ 400$ million and has the fifth rank among pharmaceutical companies in the Middle East. In Jordan now, 19 pharmaceutical factories with investment amounting to $\$ 6.5$ billion. The pharmaceutical exports have grown to $8 \%$ of total Jordanian exports. The current market of pharmaceutical exports is more than 60 countries worldwide with revenues reached to JD 600 million for 2017. The figures indicate that $80 \%$ of pharmaceutical exports for Saudi Arabia, Iraq, Algeria, Sudan, America and Europe Markets (Amman Chamber of Industry, 2017).

The planning of marketing communication activities using the balanced scorecard may give the pharmaceutical companies added values and large opportunities in the targeted markets. The effective communications may inform, persuade and impact on the potential buyers to adopt the pharmaceutical products easily, recall of information and positive buying behaviors may enhance.

The correlation between planning of marketing communication activities and balanced scorecard measures may give the pharmaceutical industry massive possibility of accessing, reaching and transferring the information needed in interactive and persuasive ways. This relationship enhances the positive WOM and products adaptation on less efforts and costs. The panning of communication strategy is part of the marketing philosophy based on fulfilling the customer needs, and the marketing process starts and ends with same consumer.

\section{Research Objectives:}

1. Diagnosing the statistical effect of customers' perspective on planning of marketing communication activities of Jordanian Pharmaceutical companies at the statistical significance level 0.05 .

2. Diagnosing there statistical effect of customers' perspective on planning of marketing communication activities of Jordanian pharmaceutical companies at the statistical significance level 0.05 .

3. Diagnosing the statistical effect of internal perspective on planning of the marketing communication activities of Jordanian pharmaceutical companies at the statistical significance level of 0.05

4. Diagnosing the statistical effect of learning and growth perspective on the planning of marketing communication activities of the Jordanian pharmaceutical companies at the statistical significance level 0.05 .

5. Determining the statistical differences in the market share of the Jordanian pharmaceutical companies according to level of using the BSC at the significance level 0.05 .

6. Determining the statistical differences in the level of market shares of the Jordanian pharmaceutical companies according to level of planning in marketing communication activities at the level of significance 0.05 .

\section{The Literatures Review:}

4.1 Balanced Scorecard:

The BSC is card represents a different perspective that formulate the strategic direction of organizations toward future performance, and it seems a measure of operational performance as well. This card not only uses the 
financial measures but also non-financial measures to shape clear overall picture of business performance, and best way to achieve such performance. This card is a set of indicators and key success factors of business performance, so it seems a sequent interrelated variable such as goals, measures and procedures (Kaplan, 2005). The card is a tool used to motivate strategic units within business, measure the progress level and changes in such units (Kaplan \& Norton, 1996, p.51).BSC is consisted of four signs: financial, customer, internal process, learning and growth, thus it is providing a balanced view of operational performance as well as the future direction of business performance (Kaplan\&Norton,1996, p.53).

The BSC defines the size of information available for strategy, as well as the level of information needed, the obstacles facing such strategy, and how this information lead the organization into future (Abdalkrim,2013). The BSC is provide timely accurate different information (Kaplan\&Norton, 1992, p.71). It is designed to meet the informational needs of managers and give them a clear comprehensive picture of organization (Van Der Zee\& DE Jong, 1999, p.199). This card also introduces four integrated dimensions combined with financial and nonfinancial measures (Adhiambo, 2014), so it has interactive relationships between strategic directions and operational processes (Certo,1995, p.6). Hoque (2014) adds that the four perspectives are: financial, customers, internal processes, and learning and growth (Idris, Hamzah, Sudirman\&Hamid, 2017).

This BSC represents a set of sequent signs combined with the strategic success factors of organization such as continuous improvement, community participation, team works and global measures of performance. This card is divvied the business vision into sub procedures and processes looking for the future. It represents also the correlation between information systems, requirements and strategy management, thus BSC enables the organization to compatible decisions in all different managerial levels and strategic divisions (Mintzberg, 2004).

Finally, BSC provides a set of quantifiable and strategic elements the organization, created by Kaplan and Norton in 1992, it aims at diagnoses the total performance of organization. BSC is a philosophy reflects three main components: measurement system, strategic management system, and the communications used (Bremser\&Barsky, 2004). It provides a logical realistic relationship among vision, mission, strategic objectives and desired outcomes according to number of indicators combined with needs of stakeholders, financial, internal processes and competencies (Kaplan \&Norton 2015), finally, BSC includes a set of financial and non-financial measures reflect business performance as well (Kaplan \&Norton 2015).

\subsection{Planning of Marketing Communication Activities:}

Marketing communication is one of the effective forms of communication aims at exploit the communication function to achieve business objectives (Odunlami \&Ofoegbu, 2011, p.408). There are different objectives looking for sending the timely accurate messages from organization to the public and controversy (Krishnamurthy, 2000, p.38). MC activities are used as promotional tool to achieve the positive contact with target market (Kanibira, Saydanb\&Nartc, 2014, p.14). Persuading the potential customer for product adaptation through storing and recalling certain information needed about goods and services produced (Odunlami et al, 2011, p.408; Maselli\& Jennifer, 2000, p.32). MC activities is a group of contacts by producer into prospective buyers in order to informing, persuading, motivating and purchasing behaviors (Schultz,1993), As well as MC activities are communicative tools designing within the marketing context in order to exchange the needed suitable information between buyers and sellers (Belch\&Belch,2004).

Marketing communication seems a complex process consists of set of variables that link between changeable goals and marketing environment (Low, 2000). Under the marketing activity dominant, delivering and handling the product to selling and consumption points is very important issue (Lerkjarijumpon, 2015, p.349). Hence, the communicative dimension is an evident comes within in the wide context (definition) of marketing which include different efforts aims at identifying customer needs and wants (Fisher, Maltz, Jaworski,1997, pp. 56-57). The customer needs and wants tends to quality, quantity and fair prices of product (Lerkjarijumpon,2015, P.350), using optimal distribution points at the right time and place, and promotional efforts aim at creating image, expanding target markets, changing consumers' behavior and creating the effective demand (Kitchen\&Schultz,2003, p.82). the successful marketing communication strategy ensures product excellence, positive image of business and its products, and enhancing long run profitable relationships with public (Banerje, Siddhanta\&Bandopadhyay,2012, p.311).

There are many changes affected marketing communication environment such as low effective of mass communication, fragmentation of consumer markets (Keller, 2009; Nowak\&Phelps,1994), and expanding of marketing communication internet platforms (Mulhern,2009, p.91). All previous literatures explain the importance of planning in communication activities and evaluating the strategic of businesses (Duncan\&Caywood,1993, p.18). the merging between MC and strategic position will be clear, consistent and compatible impacts on target audiences (Saeed, Naeem, Bilal \&Naz,2013, p.124). The strategic control of all corporate messages will promote positive dialogue between company and public, and this achieve the profitable long run relationships (Duncan\&Moriarty,1998, p.113).

The literatures confirm that economic crises, bankruptcy of organizations, and lacking of competition are factors have playing an important role in changing the work techniques, management practices, planning methods, and 
future perspectives as well as methods of forecasting (Fleisher\&Bensoussan,2002). The traditional measures based on personal experience, observation and historical indicators which were inefficient in achieve business objectives or avoid the future challenges and events, so the strategic planning seems alternative modern solution in managing the future and long run survival and growth (Idris,Hamzah\&Sudirman,2017).

Through strategic planning, the success of organization, and the synergy among marketing, production, R\&D, finance and human resources strategies with business environment can be achieved (Hua\&Lee, 2014). The strategic planning is looking for unify all operational strategies to achieve the profitable goals in target market (Atkinson\&Epstein,2000). The strategic planning also ensures increasingly adaptation of businesses with local environments. So this communication is adopted quickly and effectively with emerging changes and new conditions (Kotler\&Keller, 2007). The absence in strategic approach will reduce the communication effectiveness and marketing role in designing successful business plans. Incorrect visions, weak procedures, ambiguity of objectives, confusion of business units are causes of lower use of strategic planning (Malina,Nørreklit\&Selto,2007).

More specifically, the planning of marketing communication activities is very important tool of businesses, because of the highly interacted among business units and activities within planned organization. The effectiveness in current marketing strategy depends on the integration with marketing communication strategy (Maselli, 2002). So enhancing the communicative role of strategy requires efficient planning of marketing communications and working together using the appropriate tools to maximize the strategic impact of communicative strategies (Costa,2015).

Planning of marketing communication activities using balanced scorecard enables organizations using advantages of communication during searching process on potential customers. This planning improves the communicative capability with customers, and it can receive the precise feedback which is used in formulating the communicating strategies effectively and efficiently, and it is be able controlling all sent messages, and the profitable long run relationships can be achieved (Kotler\&Keller, 2006). There is no doubt that planning of marketing communication activities plays a vital role in improving sent messages to the target markets, so the persuasive ability and the improvements in sales and profits are achieved as well (Abhijit, 2012, P.14). Planning of marketing communication improves return on investment ROI (Chelliah\&Kwon, 2011), enhances brand image and supports customers' satisfaction and loyalty (Yaa, Okyere, Agyapong\&Nyarku, 2011, p.53).

\subsection{Impact of BSC on Performance:}

The BSC considers a measurement system allows for reviewing the physical decisions and tangible results like the financial issues, as well as assessing the intangible indicators such as customers' awareness, innovation, buying incentives and motives and brand image (Christesen, 2008). Evaluating the assets and studying the causal relations by BSC measures, encourage the executive managers using the performance components that ensure the balance between business strategy and its objectives (Wangari, Anyango\&Wanjau, 2012). The business has different objectives distributed on different levels of management within organization such as time, quality, performance, augmented services, trust and loyalty (Bourne, 2002). All of such factors used to increase the efficiency and profitability indicators (Khan, Khalique\&Nor, 2014). Wasatorn (2012) considers BSC system as the most influential factor in managing organizations, because of its vital role in improving the intellectual capacity of managers and enhancing shareholders' satisfaction, and increases the service quality as well (Ondieki,2017).

BSC supporters believe that financial success is an essential part of business performance (Tayles,Bramley,Adshead\&Farr,2002).However, the non-financial measures are key tools in improving profitability, organizational performance and unifying the processes used within organization(Davis\&Albright,2004). The BSC achieving the consistency among strategies, activities, goals and business vision (Chaudron,2003). In spite of the advantages and benefits included in BSC, many researchers believe that the relationship between BSC and strategic planning is still rigor (Davis\&Albright, 2004), and depending on large number of standards within BSC, may make it unbalanced (Ghassan,2011).

It is quite certain that BSC is a good framework enables the organizations achieving the successful implementation of strategy used, and also it provides adequate linkages among the complex actives, business strategies and strategic goals of businesses (Alao,2013). However, BCS supports a clear understanding of causal relationships and linkages within organization, which improves the corporate governance, level of integrating among people, goals, initiatives and resources on the long and short terms (Franco\&Bourne,2003). Braam and Nissen (2004) confirm that managers have no abilities in formulating appropriate strategies, so BSC considers the key tool in controlling, screening, understanding and adopting the businesses with environmental changeable factors (Ondieki,2017). They argue that managers need the pre readiness and preventive actions for unexpected changes that could happen in the external environment, so that the differences between the business strategy and customers' expectations will decrease (Atkinson\&Epstein,2000). 


\section{Research Model:}

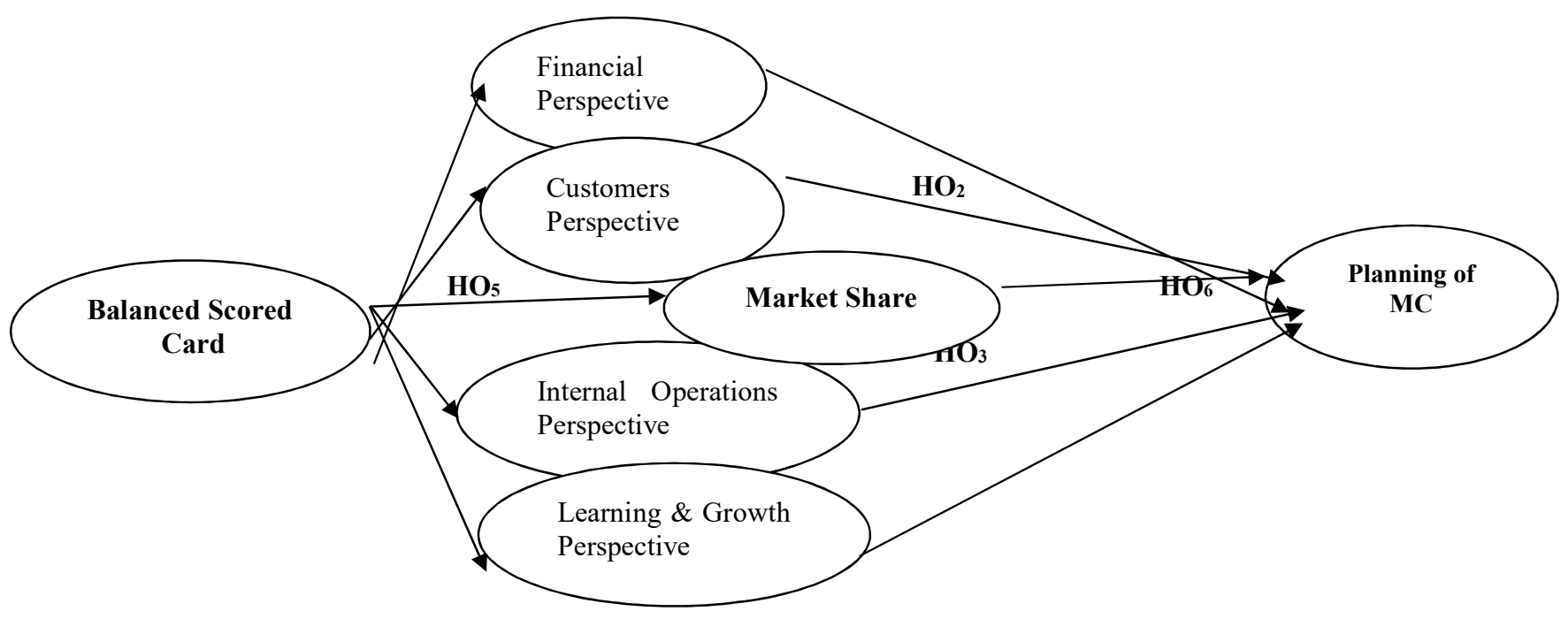

Research Conceptual Model According to Carol, 1988

So, the research hypothesis can be formulated as follow:

1. $\mathrm{H}_{1}$ : There Is a Statistical Significant Effect of Financial Perspective on Planning of Marketing Communication Activities of Jordanian Pharmaceutical Companies at the Statistical Significance Level 0.05 .

2. $\mathrm{HO}_{2}$ : There Is a Statistical Significant Effect of Customers Perspective on Planning of Marketing Communication Activities of Jordanian Pharmaceutical Companies at the Statistical Significance Level 0.05 .

3. $\mathrm{HO}_{3}$ : There Is a Statistical Significant Effect of Internal Perspective on Planning of the Marketing Communication Activities of Jordanian Pharmaceutical Companies at the Statistical Significance Level of 0.05

4. $\mathrm{HO}_{4}$ : There Is a Statistical Significant Effect of learning and growth perspective on the Planning of Marketing Communication Activities of the Jordanian Pharmaceutical Companies at the Statistical Significance Level 0.05 .

5. $\mathrm{HO}_{5}$ : There are Statistical Significant Differences in the Market Share of the Jordanian Pharmaceutical Companies According to level of Using the BSC at the Significance Level 0.05 .

6. $\mathrm{HO}_{6}$ : There are Statistical Significant Differences in The level of Market Shares of the Jordanian Pharmaceutical Companies According to the level of Planning on the Marketing Communication Activities at the Level of Significance 0.05 .

\section{Method:}

6.1 Research Type: This research is descriptive, and it aims at diagnosis the impact of BSC on planning of the marketing communication activities in Pharmaceutical companies in Jordan.

6.2 The Pilot Study: it consists of $10 \%$ of the sample size reached to 23 observations, in order to identify the characteristics of workers in the survived pharmaceutical companies, and to calculate the research population, and to determine the unit of analysis precisely.

6.3 Research Population: Consists of all mangers in the survived pharmaceutical companies or their representatives. The data indicate that $4.8 \%$ of the workers in the Jordanian pharmaceutical companies are managers. The total number of companies in the sector is 19 companies, and the total number of workers in such companies reached to 12000 in 2016 . The bachelor holders are $67 \%$ of total workers while the females accounted for 37\% (Amman Chamber of Industry, 2016), therefore the population size is 576 observations $(4.8 \% * 12000)$.

6.4 Unit of Analysis: The analysis unit consists of the executive managers of units and departments related to strategic planning, public relations, customers service, sales and marketing, operations, production, research and development ...etc. the total numbers of targeted managers reached to 576 observations or their deputies. 
6.5 Research Sample: the cluster random sample is used. The sample consists of the top management of survived pharmaceutical companies operating in Jordan. 231 observations are drawn from the population as follow:

- The total number of workers in the pharmaceutical sector as a whole was set at about 12,000 .

- Based on the pilot study, the percentage of executive managers is about $4.8 \%$ or 576 individuals.

- The number percentage of females in the sample is 86 female workers.

- The number of bachelor holders of the total sample is 155 individuals.

- 231 questionnaires were distributed to, and 225 questionnaires were returned which constituting about $97.4 \%$ of the total distributed questionnaires, as shown in the following table1:

Table 1: Research Sample Framework

\begin{tabular}{|c|c|c|c|c|c|}
\hline The Company & $\begin{array}{l}\text { Number of Distributed } \\
\text { Questionnaires }\end{array}$ & The Company & $\begin{array}{l}\text { Number of Distributed } \\
\text { Questionnaires }\end{array}$ & The Company & $\begin{array}{l}\text { Number of Distributed } \\
\text { Questionnaires }\end{array}$ \\
\hline 1 & 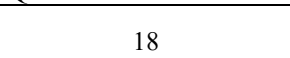 & 7 & 12 & 14 & 10 \\
\hline 2 & 18 & 8 & 11 & 15 & 9 \\
\hline 3 & 18 & 9 & 12 & 16 & 10 \\
\hline 4 & 15 & 10 & 11 & 17 & 10 \\
\hline 5 & 15 & 11 & 12 & 18 & 9 \\
\hline 6 & 15 & 12 & 12 & 19 & \\
\hline 7 & 15 & 13 & 11 & & \\
\hline
\end{tabular}

\subsection{Methods of Data Collection}

6.6.1 The Secondary Data: The review of the various literature related to the subject of this study, the Arabic and English books and theses, in addition to professional websites and formal statistics issued by the specialized institutions.

6.6.2 The Primary Data: In order to answer the research questions and to test the hypotheses, the appropriate measurement tool (questionnaire) is developed to collect the primary data from research population. The questionnaire is developed according to previous studies and literatures review related to the research variables. In order to test the research hypotheses, Cronbach's alpha coefficients are calculated in table 2 as follow:

- $80 \%$ of all professors have agreed all indicators included in the four perspectives in the questionnaire. But some modifications in editing and wording are needed. The four professors are working in Saudi and Jordanian universities.

- Cronbach's alpha is a measure of internal consistency, that is, how closely related a set of items as a group. It is considered to be a measure of scale reliability. Cronbach's alpha is not a statistical test - it is a coefficient of reliability (or consistency). The Cronbach alpha coefficients of research variables between 0.75 (Planning of Marketing Communication Activities) and (Learning and Growth Perspective) 0.987. This means that the two variables have relatively accepted. Internal consistency of all sub variables and all of the coefficient values (0.899) are statistically accepted since it is more than the statically permitted rate $60 \%$ (70\% sometimes). Guttman Split-Half test is dividing the responses obtained into two parts, then calculating the correlation coefficient between them. The high value of the correlation coefficient indicates that the responses of the two parts are very closer. The coefficient of planning in marketing communication reached to 0.82 , and the $\mathrm{BSC}$ reached to 0.966 while the total of all variables is 0.934 . So this results are statistically accepted.

Table 2: Cronbach's Alpha \& Guttman Split-Half Coefficients of Research Variables

\begin{tabular}{|c|l|c|c|}
\hline N & \multicolumn{1}{|c|}{ Research Variables } & Cronbach's Alpha & Guttman Split-Half \\
\hline 1 & Financial Perspective & 0.926 & 0.947 \\
\hline 2 & Customers Perspective & 0.914 & 0.94 \\
\hline 3 & Internal Processes Perspective & 0.919 & 0.979 \\
\hline 4 & Learning and Growth Perspective & 0.987 & 0.998 \\
\hline \multicolumn{2}{r}{ Balanced Scored Card BSC } & 0.937 & 0.966 \\
\hline 5 & Planning of Marketing Communication Activities & 0.75 & 0.82 \\
\hline \multicolumn{2}{r}{ Total Variables } & 0.899 & 0.934 \\
\hline
\end{tabular}




\section{Data Analysis and Testing the Hypotheses:}

Statistical analysis using SPSS program version 24. Descriptive statistical tools such as mean, median, and standard deviation are used to test the data obtained from research sample. The other statistical methods used to test the hypotheses such as $\mathrm{F}$ and $\mathrm{Ch}^{2}$ tests, in addition to the Pearson correlation coefficient (r), modified adjusted $\mathrm{R}^{-2}$ and Wilks lambda are calculated.

7.1 HO $\mathrm{HO}_{1}$ : There Is a Statistical Significant Effect of Financial Perspective On the Planning of Marketing Communication Activities of Jordanian Pharmaceutical Companies at the Statistical Significance Level of 0.05 .

The financial perspective is a measure of relative importance of profit margins for shareholders and investors, but at the same time it measures of the actions and procedures conducted by survived companies to achieve such profit. The profit indicators have great importance of the company management. For example, most organizations allocating the financial budget on different periods in the plan, and performance measure is based on the percentage of money spent, but at this time the financial measures are more strategic.

\begin{tabular}{|c|c|c|c|c|c|c|}
\hline No. & Phrase & $\begin{array}{l}\text { Available \& } \\
\text { Fully } \\
\text { Applied \% }\end{array}$ & $\begin{array}{c}\text { Available but } \\
\text { not } \\
\text { Applied \% }\end{array}$ & $\begin{array}{l}\text { Not } \\
\text { Available\% }\end{array}$ & Mean & S.D \\
\hline 1 & $\begin{array}{l}\text { There is a tool to measure the percentage of financial waste in your } \\
\text { company. }\end{array}$ & 65.5 & 0.00 & 34.5 & 2.32 & 0.969 \\
\hline 2 & There are tools to measure the return on investment in your company. & 82.8 & 0.00 & 17.2 & 2.85 & 0.666 \\
\hline 3 & Your management has a tool to measure the growth rate of revenues. & 75.9 & 0.00 & 24.1 & 2.6 & 0.850 \\
\hline 4 & $\begin{array}{l}\text { There is a tool to define the financial objectives and needs in your } \\
\text { company. }\end{array}$ & 62.1 & 0.00 & 37.9 & 2.37 & 0.973 \\
\hline 5 & There are clear financial programs for different activities of your company. & 55.2 & 0.00 & 44.8 & 2.138 & 1.176 \\
\hline 6 & $\begin{array}{l}\text { There are financial measures discussed by top management in your } \\
\text { company (growth in revenues, ROI, profitability, ROA). }\end{array}$ & 72.4 & 3.4 & 24.1 & 2.769 & 0.861 \\
\hline 7 & There are short and long term financial plans in your management. & 62.1 & 0.00 & 37.9 & 2.277 & 0.973 \\
\hline 8 & There is a monitoring of yearly financial needs in your company. & 48.3 & 0.00 & 51.7 & 1.76 & 0.966 \\
\hline 9 & There are updated methods of using financial budgets in your company. & 75.9 & 0.00 & 24.1 & 2.52 & 0.878 \\
\hline 10 & There are tools to measure the feasibility of investments of your Company. & 86.2 & 3.4 & 10.3 & 2.75 & 0.675 \\
\hline 11 & Total & 68.64 & 0.68 & 30.66 & 2.4354 & 0.8987 \\
\hline
\end{tabular}

The financial perspective takes into account customer's attention to quality, quantity of performance, product, timing, and cost. The results show that $68.6 \%$ of the Jordanian pharmaceutical companies fully implement their financial objectives, needs and standards. This does not prevent the implementation of some short and long term financial plans, and $48.3 \%$ of companies monitor the new annual financial needs. It was found that $55 \%$ of the companies have clear financial programs to implement the activities and identify the different needs for them, and found that $65 \%$ of the companies have an interest in reducing the financial waste and improve the exploitation of available financial resources, the financial decision in Jordanian pharmaceutical companies is centralized because it is linked to public spending plans and policies. For the company, and therefore rationalization of spending is one of the main objectives pursued by these companies.

In general, $72.4 \%$ of pharmaceutical companies in Jordan have applied investment criteria and indicators and the resulting financial returns are discussed at the company's senior management level, because the profit target is at the core of their business and the essence and basis of their presence in the target market.

On the other hand, in order to test the impact of the of financial measures and procedures on the planning of marketing communication activities in Jordanian pharmaceutical companies, table 4 shows that there are high statistical significant correlations between most financial measures and marketing communication activities through Pearson correlations. According to tabulated (42.6) and calculated (45.9) value of $\mathrm{Ch}^{2}$, we accept the statistically effect of financial perspective on planning of marketing communication activities of Jordanian pharmaceutical companies at the statistical significance level of 0.05 .

The table also indicates that the Wilks Lambda value means that the measures and procedures listed in the financial perspective explain $83.8 \%$ of the variation in planning of marketing communication activities, and $16.2 \%$ refers to other financial measures not listed here. The correlation coefficients show the relationships between the "there is a tool to define the financial objectives and needs in your company ' and "there is a monitoring of yearly financial needs in your company", "there is a monitoring of yearly financial needs in your 
company" with the planning of marketing communication activity reached to the highest level of correlation $98 \%$. While the weak relationship is between "there are tools to measure the feasibility of investments of your Company' and the dependent variable $68 \%$.

Table 4: The Statistical Indicators of Effect the Financial Perspective on Dependent Variable

\begin{tabular}{lcccccccccccc}
\hline \multicolumn{1}{c}{ Phrase } & $\mathbf{1}$ & $\mathbf{2}$ & $\mathbf{3}$ & $\mathbf{4}$ & $\mathbf{5}$ & $\mathbf{6}$ & $\mathbf{7}$ & $\mathbf{8}$ & $\mathbf{9}$ & $\mathbf{1 0}$ & \\
Number & & & & & & & & & & \\
\end{tabular}

7.2 $\mathrm{HO}_{2}$ : There Is a Statistical Significant Effect of Customers Perspective on Planning of Marketing Communication Activities of Jordanian Pharmaceutical Companies at the Statistical Significance Level 0.05 .

Table 5 indicates that $74.7 \%$ of the measures reflect the interests and needs of customers and stakeholders of the pharmaceutical industry in Jordan are not available in such companies. There is also a large variation in application the indicators and measures among the companies survived. It is clearly shown that most of indicators not available in the pharmaceutical companies in Jordan, which means that there is weakness in the surveyed companies in addressing the needs of customers and stakeholders.

There 9 out of 11 indicators have average more than 2, which means that application level of such indicators are low. Two out of 11 indicators listed in the table 5 are the most applied in the surveyed companies. It finds that $48.3 \%$ of pharmaceutical companies in Jordan has an effective mechanism in studying the customers' complaints. $41.4 \%$ of such companies have tools of measuring the growth rate of beneficiaries from products provided. The increased attention with such tools comes because of the importance of pharmaceutical products (medicines) to human life and sustainability, so this measures is necessary for companies as a part of global standardization in the field of pharmaceuticals industry.

Table5: Descriptive Statistics of Customers Perspective

\begin{tabular}{|c|c|c|c|c|c|c|}
\hline No & Phrase & $\begin{array}{l}\text { Available \& } \\
\text { Fully } \\
\text { Applied \% }\end{array}$ & $\begin{array}{c}\text { Available but } \\
\text { not } \\
\text { Applied \% }\end{array}$ & $\begin{array}{c}\text { Not } \\
\text { Available\% }\end{array}$ & Mean & S.D \\
\hline 1 & $\begin{array}{l}\text { The Tools of measuring customers' satisfaction are available in your } \\
\text { company. }\end{array}$ & 20.7 & 0.00 & 79.3 & 3.862 & 0.850 \\
\hline 2 & $\begin{array}{l}\text { Tools of measuring the growth rate of customers are available in your } \\
\text { company. }\end{array}$ & 41.4 & 0.00 & 58.6 & 2.724 & 1.246 \\
\hline 3 & $\begin{array}{l}\text { There is an effective mechanism for customers' complaints in your } \\
\text { company. }\end{array}$ & 48.3 & 10.3 & 41.4 & 2.937 & 0.916 \\
\hline 4 & $\begin{array}{l}\text { There are tools of measuring the level of participation of customers in the } \\
\text { in events and programs organized by your company. }\end{array}$ & 17.2 & 0.00 & 82.8 & 2.552 & 0.785 \\
\hline 5 & $\begin{array}{l}\text { The tool of measuring the satisfaction of governmental partners are } \\
\text { available in your company. }\end{array}$ & 13.8 & 0.00 & 86.2 & 2.410 & 0.786 \\
\hline 6 & $\begin{array}{l}\text { The checklist of measuring the relationship between customers and the } \\
\text { company is available. }\end{array}$ & 10.3 & 3.4 & 86.2 & 2.7586 & 0.634 \\
\hline 7 & $\begin{array}{l}\text { The list of the complaint VIP customers and beneficiaries is available in } \\
\text { your company. }\end{array}$ & 10.3 & 3.4 & 86.2 & 2.7586 & 0.656 \\
\hline 8 & $\begin{array}{l}\text { The tools of measuring quality of customers are available in your } \\
\text { company. }\end{array}$ & 24.1 & 0.00 & 75.9 & 2.5172 & 0.879 \\
\hline 9 & $\begin{array}{l}\text { The tools of increasing the social responsibility are available in your } \\
\text { company. }\end{array}$ & 10.3 & 6.9 & 82.8 & 2.7241 & 0.649 \\
\hline 10 & $\begin{array}{l}\text { There is a public relations device of measuring and improving the image } \\
\text { of your company. }\end{array}$ & 31 & 6.9 & 62.1 & 2.3103 & 0.980 \\
\hline 11 & $\begin{array}{l}\text { The ratio of new services provided / new customers is calculated in your } \\
\text { company. }\end{array}$ & 24.1 & 3.4 & 72.4 & 2.4828 & 0.879 \\
\hline 12 & $\begin{array}{l}\text { The Tools of monitoring the changes in external environment are } \\
\text { available in your company. }\end{array}$ & 17.2 & 0.00 & 82.8 & 2.6552 & 0.765 \\
\hline \multicolumn{2}{|r|}{$\begin{array}{ll}\text { Total } \\
\end{array}$} & 22.39167 & 2.858333 & 74.725 & 2.72432 & 0.83542 \\
\hline
\end{tabular}

The level of applying the indicators and measures of customers' perspective in the Jordanian pharmaceutical companies is very weak according to $74.7 \%$ of the companies surveyed. There are many examples of such weak measures such as the tools of measuring customers' satisfaction, the tool of measuring the satisfaction of governmental partners, the checklist of measuring the relationship between customers and the company is available, the tools of increasing the social responsibility are available in your company as well as the tools of 
monitoring the changes in external environment.

In general, the level participation of the Jordanian pharmaceutical companies with local community is isolated from the real interests and requirements or of the beneficiaries and customers. Therefore, the pharmaceutical companies play the oligopolistic role on the local market, and the products manufactured according to sellers' vision rather than the buyer. This type of markets allow the Al-Hikma Factory has more than 50\% of the market share in Jordan. These type of companies is profit-oriented, and designing the pharmaceutical has maximizing the oligopolistic conditions, through providing products don't take the high standards of quality, or customers' opinions in its considerations.

In order to test the second hypothesis, table 6 shows that there are very low and insignificant statistically relationships among all measures of customers' perspective with planning of marketing communication activities. Based on the calculated $\mathrm{Ch}^{2}$ test (17.8) and tabulated value (42.6) of test, we can say that there is no statistical effect of customers and beneficiaries' perspective on planning the marketing communication activities of Jordanian pharmaceutical companies at the statistical significance level 0.05 . The table also indicates that the value of Wilks Lambda means the measures and procedures in this card don't explain more $33 \%$ of the variation in the planning of marketing communication activities, and that remaining percent $(67 \%)$ is refers to other unlisted factor in this analysis.

\begin{tabular}{|c|c|c|c|c|c|c|c|c|c|c|c|c|}
\hline $\begin{array}{l}\text { Phrase Number } \\
\text { Dependent Variable }\end{array}$ & 1 & 2 & 3 & 4 & 5 & 6 & 7 & 8 & 9 & 10 & 11 & 12 \\
\hline Planning of MC Activities & -.011 & 0.047 & 0.063 & -0.271 & -0.14 & -0.068 & -0.068 & 0.032 & -0.152 & -0.11 & 0.047 & 0.063 \\
\hline
\end{tabular}

7.3 $\mathrm{HO}_{3}$ : There Is a Statistical Significant Effect of Internal Perspective on Planning of the Marketing Communication Activities of Jordanian Pharmaceutical Companies at the Statistical Significance Level of 0.05 .

Table 7 shows that $66.5 \%$ of the indicators that reflect operations and procedures are not available mainly to Jordanian pharmaceutical companies. The arithmetical averages of these indicators show values greater than the general arithmetic mean (2), ranging from 2.103 to 2.872 . The first phrase, "there is a tool to measure the new services your company provides to the public" is obtained on the higher average. In contrast, the phrase "there is an instrument to measure the input / output ratio in your company" obtained the lowest value, indicating that most respondents have similar views on the lack of process measurement tools and $32 \%$ of these indicators are available but vary in importance between the companies / departments under study.

Time, as the fifth element of production function is idle, and it is underutilization level in many of Jordanian pharmaceutical companies. The productivity of the labor during working time is very low, this result reflects the lacking of time-wasting tools relative to the total work time. $85.6 \%$ of the surveyed companies, and $77.9 \%$ of the companies are still neglecting the calculations of the time needed to accomplish the work or certain goals. It finds that $41 \%$ of the Jordanian pharmaceutical companies use distinguished procedures comparing to other competitors such as innovation, information systems and speed, so most of this companies aren't looking for improve accuracy, speed and quality services to target audience.

In order to test the impact of the internal processes perspective on the planning of marketing communication activities in the Jordanian pharmaceutical companies, Table 8 shows that there are very low and unaccepted statistically correlations among all measures of internal processes perspective and Planning of marketing communication activities, the comparison between the calculated and tabulated values of $\mathrm{Ch}^{2}$ test, we decide that there is no statistical effect of the internal processes perspective on planning of the marketing communication activities in the Jordanian pharmaceutical companies. The table also indicates that the value of Wilks Lambda means that the measures and procedures in this perspective don't explain more than $2 \%$ of the variation in planning of marketing communication activities, and $98.3 \%$ of the variation refers to procedures and measures not listed in this perspective. 


\begin{tabular}{|c|c|c|c|c|c|c|}
\hline No & Phrase & $\begin{array}{l}\text { Available \& } \\
\text { Fully } \\
\text { Applied \% }\end{array}$ & $\begin{array}{c}\text { Available but } \\
\text { not } \\
\text { Applied \% }\end{array}$ & $\begin{array}{c}\text { Not } \\
\text { Available \% }\end{array}$ & Mean & S.D \\
\hline 1 & There is a tool to measure the new services provided by your company. & 24.1 & 0.00 & 75.9 & 2.872 & 0.87099 \\
\hline 2 & $\begin{array}{l}\text { There is a tool to measure the high value added processes provided by } \\
\text { your company. }\end{array}$ & 13.8 & 0.00 & 86.2 & 2.741 & 0.70186 \\
\hline 3 & $\begin{array}{l}\text { There is a quality system for procedures and processes within your } \\
\text { company. }\end{array}$ & 27.6 & 3.4 & 69 & 2.534 & 0.90701 \\
\hline 4 & There is a tool to measure the quality of output in your company. & 27.6 & 6.9 & 65.5 & 2.123 & 0.90292 \\
\hline 5 & $\begin{array}{l}\text { Your company has distinguished procedures comparing to other } \\
\text { competitors (creativity, information systems, and speed). }\end{array}$ & 55.4 & 3.4 & 41.2 & 2.329 & 0.99010 \\
\hline 6 & $\begin{array}{l}\text { Your company has a tool of measuring the proportion of transactions } \\
\text { scheduled for certain time periods. }\end{array}$ & 44.8 & 3.4 & 51.7 & 2.125 & 0.99753 \\
\hline 7 & $\begin{array}{l}\text { Your company has a tool of measuring the time management foe certain } \\
\text { actions. }\end{array}$ & 13.8 & 10.3 & 75.9 & 2.207 & 0.72771 \\
\hline 8 & $\begin{array}{l}\text { Your company has a tool of measuring the percentage of waste time to } \\
\text { total time. }\end{array}$ & 3.4 & 11.0 & 85.6 & 2.655 & 0.18570 \\
\hline 9 & $\begin{array}{l}\text { Your company has a tool of measuring the wrong transactions as a percent } \\
\text { to total transactions. }\end{array}$ & 17.2 & 5.9 & 77.9 & 2.542 & 0.77998 \\
\hline 10 & Your company has a tool of measuring the quality of work process. & 24.1 & 6.9 & 69 & 2.483 & 0.86957 \\
\hline 11 & Your company has a tool of measuring the accuracy of work process. & 31 & 3.4 & 65.5 & 2.348 & 0.93640 \\
\hline 12 & Your company has a tool of measuring the speed of work process. & 27.6 & 10.3 & 62.1 & 2.448 & 0.89745 \\
\hline 13 & There is a tool of measuring the input / output ratio. & 27.6 & 13.8 & 58.6 & 2.103 & 0.89056 \\
\hline 14 & There is a tool of developing the internal processes in your company. & 37.9 & 20.7 & 41.4 & 2.345 & 0.90565 \\
\hline 15 & $\begin{array}{l}\text { There is a tool of measuring the ratio of work problems to the total number } \\
\text { of problems in your company. }\end{array}$ & 20.7 & 6.9 & 72.4 & 2.172 & 0.82897 \\
\hline \multicolumn{2}{|c|}{ Total } & 26.44 & 7.0867 & 66.5267 & 2.4018 & 0.82616 \\
\hline
\end{tabular}

\begin{tabular}{|c|c|c|c|c|c|c|c|c|c|c|c|c|c|c|c|}
\hline $\begin{array}{c}\text { Phrase Number } \\
\text { Dependent Variable }\end{array}$ & 1 & 2 & 3 & 4 & 5 & 6 & 7 & 8 & 9 & 10 & 11 & 12 & 13 & 14 & 15 \\
\hline $\begin{array}{c}\text { Planning of } \mathrm{MC} \\
\text { Activities }\end{array}$ & 0.93 & $\overline{-}$ & 0.037 & 0.039 & 0.05 & 0.053 & $\overline{-} \overline{049}$ & 0.011 & $\overline{0,116}$ & 0.032 & $\overline{0 .}$ & 0.037 & 0.039 & 0.05 & 0.05 \\
\hline $\mathrm{Ch}^{2}$ Calculated $=$ & & $=0$ & 43 & 2 tah & ated & 42.6 & Sig. $=$ & $.05 \mathrm{~V}$ & $1 \mathrm{ks} \mathrm{La}$ & $\mathrm{bda}=$ & .983 & $\mathrm{Sig}$ & $=0.24$ & & \\
\hline
\end{tabular}

7.4 $\mathrm{HO}_{4}$ : There Is a Statistical Significant Effect of learning and growth perspective on the Planning of Marketing Communication Activities of the Jordanian Pharmaceutical Companies at the Statistical Significance Level 0.05.

Table 9 indicates that $42.3 \%$ of the Jordanian pharmaceutical companies have applying the indicators and standards of learning and growth perspective. It finds that $90.8 \%$ of the surveyed companies have new methods and tools of improving the level of business operations such as computer, telephone, internet, fax, and printers ...etc. so this high percentage reflects the desire of modernization and development in Jordanian pharmaceutical companies. We also note that between $51 \%$ and $58.6 \%$ of the companies surveyed have effective and partially applied standards, mainly related to incentive and reward systems that improve employee's performance and satisfaction, design the learning and training programs of managers, having the appropriate information and communication systems, and applying the duties and responsibilities measure for managers. The analysis also concludes that $30.8 \%$ of the companies surveyed partially applied some standards related to the self-assessment of managers and using the tools of measuring the unique skills and competences of employees, and $31 \%$ of such companies have a tool of measuring the training and learning needs for managers. 


\begin{tabular}{|c|c|c|c|c|c|c|}
\hline No & Phrase & $\begin{array}{l}\text { Available \& } \\
\text { Fully } \\
\text { Applied \% }\end{array}$ & $\begin{array}{c}\text { Available but } \\
\text { not } \\
\text { Applied \% }\end{array}$ & $\begin{array}{c}\text { Not } \\
\text { Available } \%\end{array}$ & Mean & S.D \\
\hline 1 & There is a tool of measuring the employee satisfaction in your company. & 24.1 & 3.4 & 72.4 & 2.4828 & 0.87099 \\
\hline 2 & $\begin{array}{l}\text { There are education and training programs for managers in your } \\
\text { company. }\end{array}$ & 58.6 & 10.3 & 31 & 1.7241 & 0.92182 \\
\hline 3 & $\begin{array}{l}\text { There are a new methods and tools of improving the business } \\
\text { (computer, telephone, etc.). }\end{array}$ & 90.8 & 3.4 & 5.8 & 1.3103 & 0.71231 \\
\hline 4 & $\begin{array}{l}\text { There are incentives and rewards systems of employees in your } \\
\text { company. }\end{array}$ & 51.7 & 3.4 & 44.8 & 1.9310 & 0.99753 \\
\hline 5 & There are a MIS and communication systems in your company. & 55.2 & 6.9 & 37.9 & 1.8276 & 0.96618 \\
\hline 6 & $\begin{array}{l}\text { There are self-evaluation tools for managers and directors in your } \\
\text { company. }\end{array}$ & 30.8 & 0.00 & 69.2 & 2.1034 & 1.01224 \\
\hline 7 & $\begin{array}{l}\text { There is a tool of measuring of the distinguished capabilities and } \\
\text { competencies in your company. }\end{array}$ & 37.9 & 3.4 & 58.6 & 2.2069 & 0.97758 \\
\hline 8 & $\begin{array}{l}\text { There is a tool of measuring of the creation and innovation among } \\
\text { employees in your company. }\end{array}$ & 17.2 & 3.4 & 79.3 & 2.6207 & 0.77523 \\
\hline 9 & $\begin{array}{l}\text { There is a tool of sharing the knowledge and experience among } \\
\text { employees in your company. }\end{array}$ & 17.2 & 10.3 & 72.4 & 2.5517 & 0.78314 \\
\hline 10 & $\begin{array}{l}\text { There is a tool of measuring the training and learning needs of } \\
\text { managers in your company. }\end{array}$ & 31 & 13.8 & 55.2 & 2.2414 & 0.91242 \\
\hline 11 & $\begin{array}{l}\text { There is a tool of duties and responsibilities for employees in your } \\
\text { company. }\end{array}$ & 51.7 & 3.4 & 44.8 & 1.9310 & 0.99753 \\
\hline \multicolumn{2}{|r|}{ Total } & 42.38182 & 5.60909 & 51.94545 & 2.0846 & 0.905598 \\
\hline
\end{tabular}

In conclusion, $51.9 \%$ of the Jordanian pharmaceutical companies don't have the indicators of learning and growth perspective, especially those indicators related to measure the employee satisfaction $(72.4 \%)$, measuring of the creation and innovation among employees (79.3\%), measuring the distinguished capabilities and competences $(58.3 \%)$, in addition to tool of measuring the training and learning needs of managers in your company. $(55.2 \%)$

\begin{tabular}{|c|c|c|c|c|c|c|c|c|c|c|c|}
\hline $\begin{array}{l}\text { Phrase Number } \\
\text { Dependent Variable }\end{array}$ & 1 & 2 & 3 & 4 & 5 & 6 & 7 & 8 & 9 & 10 & 11 \\
\hline Planning of MC Activities & 0.288 & 0.213 & 0.084 & 0.26 & 0.235 & 0.309 & 0.355 & -0.165 & 0.039 & 0.288 & 0.213 \\
\hline $\mathrm{Ch}^{2}$ Calculated $=15.3$ & iq. $=0$. & & $h^{2}$ Tabu & ated $=$ & 42.56 & ig. $=0$. & & lks Lamb & $\mathrm{la}=0.1 \mathrm{C}$ & $5 \quad$ Sig. & $=0.243$ \\
\hline
\end{tabular}

In order to test the impact of learning and growth perspective on the planning of marketing communication activities in the Jordanian pharmaceutical companies, table 10 shows that the correlation coefficients ranging between $3.9 \%$ and $28.8 \%$ for the phrases "there is a tool of sharing the knowledge and experience among employees in your company. " and phrase " there is a tool of measuring the training and learning needs of managers in your company ", respectively, with the planning of marketing communication activities. Based on the calculated and tabulated of $\mathrm{Ch}^{2}$ values test, it can be reject the hypothesis that suppose affecting the learning and growth perspective on planning of the marketing communication activities in Jordanian pharmaceutical companies. The table also indicates that Wilks Lambda means that measures and procedures of learning and growth perspective explain $16.5 \%$ of changes in the dependent variable, and $83.5 \%$ of such measures refer to other unlisted procedures in this dimension, may be most of them are financial.

7.5 HO Ho $_{5}$ There are Statistical Significant Differences in the Market Share of the Jordanian Pharmaceutical Companies According to level of Using the BSC at the Significance Level 0.05.

The ANOVA analysis is used to test the statistical differences in the market share of surveyed companies according to level of using the BSC in such companies. The statistical rule says that if the calculated level of significance lower than 0.05, we accept the differences and contra verse (Sekaran\& Bougie, 2016).

Table 11 indicates that there are clear differences in the market shares of Pharmaceutical companies according to the level of using BSC in such companies, and this result according to the comparison between calculated and tabulated values of $\mathrm{F}$ test. The high market share of pharmaceutical companies means the high level of using of BSC in such companies according to the Pearson correlation coefficient (0.825). Scheffe test shows that this differences tend to companies that having 10\% - 15\% market share. This is consistent with Hoque and James, (2000) about impact of market share, product life cycle and company size on the results of BSC (Bourne, Neely, Platts\&Mills,2000). In real life, the improvement in the level of BSC has positive impact on the market share, thereby the high positive financial results affect the level of BSC in most of companies (look at first hypothesis 
in current research). The financial impact is a result of set of measures that improving the service quality, increasing customer relationship marketing CRM, and it has a positive impact on workers' productivity, and enhancing the level efficiency in the managerial system.

\begin{tabular}{|c|c|c|c|c|c|c|c|}
\hline Indenendent Variable & Market Share & Number. & Meon & $S D$ & $r$ & F & $\mathrm{Sin}$ \\
\hline \multirow{4}{*}{ Market Share } & Less Than $5 \%$ & 5 & 2.121 & 0.7561 & \multirow{4}{*}{0.825} & \multirow{4}{*}{9.874} & \multirow{4}{*}{0.00} \\
\hline & $5 \%$ - Less Than $10 \%$ & 3 & 2.412 & 0.3347 & & & \\
\hline & $10 \%$ - Less than $15 \%$ & 6 & 2.513 & 1.085 & & & \\
\hline & More Than $15 \%$ & 5 & 2.476 & 0.875 & & & \\
\hline
\end{tabular}

7.6 HO : There are Statistical Significant Differences in The level of Market Shares of the Jordanian Pharmaceutical Companies According to the level of Planning on the

As we shown, the ANOVA analysis helps to find the statistical differences in the effect of planning in marketing communication activities on the market shares of the surveyed companies. Table 12 indicates that there are clear differences in the market share of Pharmaceutical Companies because of the planning in the marketing communication activities. By using the statistical rule and comparing between the calculated and tabulated levels of significance (0.00) and (0.031), there is a difference in the market shares of pharmaceutical companies in Jordan according to the planning in MC activities. According to the Scheffe test, the differences tend to companies that have market shares more than $15 \%$, and this means that there is a clear positive correlation between the planning in IM activities and market share (0.887).

\begin{tabular}{|c|c|c|c|c|c|c|c|}
\hline Independent Variable & Market Share & Number & Mean & S.D & $\mathrm{r}$ & $\mathrm{F}$ & Sig \\
\hline \multirow[t]{4}{*}{ Market Share } & Less Than $5 \%$ & 6 & 1.871 & 1.018 & \multirow[t]{4}{*}{0.887} & \multirow{4}{*}{6.436} & \multirow{4}{*}{0.031} \\
\hline & $5 \%$ - Less Than $10 \%$ & 7 & 2.012 & 1.851 & & & \\
\hline & $10 \%$ - Less than $15 \%$ & 2 & 2.451 & 0.971 & & & \\
\hline & More Than $15 \%$ & 3 & 2.791 & 1.075 & & & \\
\hline
\end{tabular}

\section{Discussion of Findings, Implications and Recommendations:}

\subsection{The Discussion:}

The financial perspective is developing to create a sustainable growth in shareholders' value and enhance the profitability (Crabtree\&DeBusk,2008). Kaplan and Norton (2001) consider the financial information to is one of the basic needs for decision makers and executive managers of organization, and it important to say that all jobs and activities in the business firms are profit oriented, so this mission making the financial performance is the final result of business works (Kanji\&Saa,2002). The literature shows that financial perspective consists of sat of indicators such as: profit margin, volume of income, ROA, ROI and ROE ...etc. (Kanji\&Saa,2002). In this context, it finds that the financial perspective is highly applied in the pharmaceutical companies in Jordan (73\%), thus, this perspective has the strategic importance rather than other perspectives in BSC. Most of the surveyed companies are completely implement the financial performance measures, and they have activities correlate with long run financial programs. The pharmaceutical companies focus on the financial resources productivity in the strategic context, in addition to the accounts of ROA, ROI, and total revenues, and the profit criterion is one of the core missions and basics of business in the real life and target markets.

In current study, there is a strong impact of the financial card on the planning of marketing communication activities in the surveyed companies, and the correlation reached to $83.8 \%$ between them. The current financial measures provide a wide overview about the financial needs for marketing communication activities, and this card connects between such financial needs with desired objectives. This means that the Jordanian pharmaceutical companies use the goals based approach when allocating the marketing communication budget. Companies also use the tools that measure the investment feasibility in some communicative activities. These results are consistent with the results that showed that financial measures have play a strong role in making the equilibrium between the internal resources and external opportunities (Malina,Nørreklit\&Selto,2007). The amount of information also affects the formulating of the communication strategy, thus the financial performance and level of decision making will be affected (Najjar\&Kalaf,2012). It is clear that there is a high positive correlation among financial measures, product quality, staff performance, and financial performance of organization (Sohani\&Singh,2014). The financial improves the financial control, managerial system in the organization, assets utilization and cost structure (Kairu, Wafula, Okaka, Odera\&Akerele,2013), and as a result it improves the level of performance in all organization (Sahiti,Ahmeti, Sahiti\&Aliu,2016).

The customers' perspective includes four sub measures customers' satisfaction, product, human resources and the process, and such measures have vital importance in influencing on the customers' perceptions toward the organization and its products, and improving profitability levels as well (Sureshchandar,Rajendran\&Anantharaman,, 2002). The customers' perspective also determines the market value of the company, because the modern marketing philosophy shows that the customer has an important role in 
determining the level of quality within the organization and, there is a positive strong correlation between the customers' concerns and satisfaction level. As a result, the less customers' concerns is a key indicator of business decline in spite of financial feasibility at current time. So the customers' satisfaction and meeting their needs and requirements are supporting elements of business growth (St Clair,1997).

Measures of Customer perspective reduce the customer's complaints and increase the customers' retention for long time (Zairi\&Jarrar,2000).Kaplan and Norton (1992) add that customers satisfaction on of critical success factors of organization (Wongrassam\&Simmons, 2003), and creates high value on the long term (Niven, 2003) and improves the business image (Kaplan\&Norton,2004), and other results have determining that $51 \%$ of organizational performance refers to customers perspective (Marete,2015), in addition to the positive correlation among customers satisfaction, service quality and employees performance is approved (Najjari et al.,2015). Current research results show that the customers' perspective is not applied in the pharmaceutical companies in Jordan according to $75 \%$ of such companies. There is a gap in application of customers' perspective comparing to Al-Hikma Company, which has $50 \%$ of the exporting market in Jordan. The most applicable measures in this perspective are: there is an effective device of customers' complaints and there is a toll of measuring the growth in the market share and customers.

In conclusion, the pharmaceutical companies have lacking in application the sub measures in the customers' perspective, and the marketing activities independently conducted of the customers concerns, requirements, provisions and wants, so these behaviors by pharmaceutical companies have reduced the positive effects of customers' perspective on the planning of marketing communication activities . In details the pharmaceutical companies have lost the advantages of internal processes based on customers concerns (Kaplan\&Norton,2010), or in product quality improvements (Hoque \&James,2000;Kaplan\&Norton, 2004), and customers comfort (Hoque\&James,2000). The weakness in application of customers' perspective decrease of understanding the external environment and discovering more opportunities and customers (Kaplan\&Norton,1996). These results affect also product prices and brand value. The WOM and customers will move to other competitors in the case of the appropriate alternatives are available (Kotler\&Armstrong,2004). Building profitable relationships with customers is decreased (Fazli1, MafiYeganeh\& HashemiSiavoshani,2013).

The internal processes perspective helps in identifying the critical needed processes of the organization in order to adding new values of customers and achieving the compatible competitive advantages with business objectives (Kaplan \& Norton,1996). Internal processes perspective explain the internal processes required to enhance the customers' satisfaction, to explore the managers' expectations, to meet employees' needs and the consistent with business standards (Amaratunga, Baldry\&Sarshar, 2001). Our current results also emphasize that internal processes perspective is less than expectations, and many related tools, measures and techniques to such perspective are still idled, inefficient, and less utilized. Despite that there is small proportion of such tools are using in areas of innovation, information systems, regulation and speed. Therefore, the internal processes have no strong impact on the planning of marketing communication activities according to $98.3 \%$ of surveyed companies. These companies still lacking of concerns of employees, customers' satisfaction, cost indicators, time and quality (Sureshchandar,2005).

Finally, the learning and growth perspective includes a set of indicators such as staff capacity (skills, talents, knowledge and training), quality of information systems (systems, databases and networks), and the impact of organizational consistent (culture, leadership, alignment and teamwork) (Marete, 2015). Business success in achieving the organizational goals is based on exploiting the skills of employees, accurate information and effective leadership. All of such factors are increase the products quality enhance the financial performance. More specifically, the concerns of innovation and learning through staff training, organizational culture enhancement, infrastructure attention, and organizational improving the culture are important measures to address the environmental challenges and give customers greater value. Kaplan and Norton (2000) argue that the three perspective financial, customers and internal processes may create a gaps in the organizational structure, but the role of growth and learning perspective is bridging those gaps using staff training and information technology (Chytas et al., 2011). However, half of the surveyed companies doesn't apply the growth and learning perspective. In spite of such result there are some temporal non institutional measures such as satisfaction and innovation among employees, improving equipment, but there lacking un effective training programs and information systems. As a result, the learning and growth perspective in Jordanian pharmaceutical companies has no an active role in planning of the marketing communication activities, as the measures of such perspective explains low percent of planning of marketing communication activities reached to $16.5 \%$.

\subsection{Practical Implications and Recommendations:}

The BSC is strategic framework used in the managerial process in planning of the marketing communication activities. The reason of using such model refers to the broad acceptance of the advantages may be achieved according to many research confirmed this. But it is important to note that few of these studies have confirmed the impact of the financial perspective only, and our current results agree that the positive relationship between financial perspective and planning of marketing communication activities in the Jordanian pharmaceutical 
companies reached to $68 \%$. This financial relationship between the two variables seems a part of the financial planning process of marketing communication activities and whish is considered the key of performance evaluation and effectiveness of the marketing communication activities used by the surveyed companies. The intended neglecting of the non -financial perspectives by surveyed companies in planning the MC activities, is unacceptable issue according literatures and previous research. Therefore, pharmaceutical companies use the financial performance as a sufficient condition to success the measures used in the financial planning process. These financial measures are transforming into financial measures that used in the three other perspectives customers' satisfaction, internal processes, learning and growth. Table 13 shows that the financial perspective is responsible of enhancing the effectiveness of marketing communication activities and improving the performance and profitability indicators of companies that have used this model. The crowding effect between the impact of financial and non-financial perspectives is de generalized because of other research and sectors have confirmed the positive correlation among the four perspectives. The privacy of the pharmaceutical products which affected human health and sustainability, the time of using, the size of target market, and the quality of equipment and techniques used are factors explain the low concerning with customer satisfaction, learning and creativity. So there is misunderstanding and difficult to unify all four perspectives in the pharmaceutical companies as well as other sectors or products.

The financial perspective is very important factor in evaluating the planning of marketing communication activities, but there is an urgent need to adjust the priorities of the pharmaceutical companies in Jordan. So the advantages and benefits of BSC require the improvement in the existing relationships between VIP customers who have high financial capabilities and large volumes of purchasing, in addition to improving the controlling levels of external marketing environment. We also add that the surveyed companies need of strengthen the time management measures and improving the performance and productivity of time by low levels of cost, errors and time wasted during transactions and deals for better values to customers. Also there a massive need of improving the internal marketing and the relations between company and employees. This philosophy will promote the positive environment of innovation among employees. As well as diffusing institutional innovation and sharing the skills and experiences among employees in the pharmaceutical industry. This will enhance the growth, sustainability and understanding the changeable external environment and reducing the conflict with such environment. All of the above are important elements in the BSC, requires increasing the level awareness among employees and managers and how such card reflects on all of activities within organizations, especially the marketing communication activities. Developing a business strategy that exploits the capabilities of the employees, using the workshops and conferences are tools of increasing level of awareness toward BSC.

\begin{tabular}{|c|c|c|c|c|c|c|}
\hline No & Phrase & $\begin{array}{l}\text { Available \& } \\
\text { Fully } \\
\text { Applied } \%\end{array}$ & $\begin{array}{c}\text { Available but } \\
\text { not } \\
\text { Applied \% }\end{array}$ & $\begin{array}{l}\text { Not } \\
\text { Variable } \%\end{array}$ & Mean & S.D \\
\hline 1 & $\begin{array}{l}\text { There are procedures of planning marketing communication activities in } \\
\text { your company. }\end{array}$ & 65.5 & 0.00 & 34.5 & 2.76 & 0.878 \\
\hline 2 & The BSC results are used in financial planning of marketing communication. & 82.8 & 0.00 & 17.2 & 2.88 & 0.427 \\
\hline 3 & $\begin{array}{l}\text { The BSC results are used to determine the appropriate marketing } \\
\text { communication tools for customers. }\end{array}$ & 75.9 & 0.00 & 24.1 & 2.79 & 0.806 \\
\hline 4 & $\begin{array}{l}\text { The BSC results are used in planning of employees needs working in } \\
\text { marketing communications. }\end{array}$ & 62.1 & 0.00 & 37.9 & 2.26 & 0.793 \\
\hline 5 & $\begin{array}{l}\text { The BSC results are used to enhance the innovation in marketing } \\
\text { communication activities. }\end{array}$ & 55.2 & 0.00 & 44.8 & 2.19 & 0.798 \\
\hline 6 & $\begin{array}{l}\text { The BSC results are used to reduce the un necessary internal processes in } \\
\text { your company. }\end{array}$ & 72.4 & 3.4 & 24.1 & 2.71 & 0.869 \\
\hline 7 & $\begin{array}{l}\text { The BSC results are used to achieve the planned financial profits of your } \\
\text { company. }\end{array}$ & 62.1 & 0.00 & 37.9 & 2.29 & 0.889 \\
\hline \multicolumn{2}{|r|}{ Total } & 68 & 0.49 & 31.5 & 2.5543 & 0.78 \\
\hline
\end{tabular}

\section{Research Limitations and Future Research:}

The objective of this study is measuring the impact of application the BSC perspectives on the planning of marketing communication activities in Jordanian pharmaceutical companies. Therefore, the research population is determining by all the pharmaceutical companies in Jordan reached to 19 companies. The sample is withdrawn from the main branches in Amman for 2018 because of the presence of such companies in the city of Amman. In general, the planning mission responsible by managers and directors in the surveyed companies, so the unit of the executive managers of units and departments related to strategic planning, public relations, customers service, sales and marketing, operations, production, research and development. etc. the total numbers of targeted managers reached to 576 observations or their deputies. The study proposes doing similar research on 
alternative sectors to identify the level of application the BSC perspectives and the impact such perspectives on the planning of marketing communication activities. These wide overview require studying the key governmental sectors that have direct relations with customers such as the ministry of health and ministry of education. At the level of the private sector, the study suggests applying on the tourism sector in general, with a focus on five-star hotels, as well as the telecommunications and airlines companies.

\section{Conclusion:}

The objective of this study is exploring the impact of the Balanced Scorecard perspectives on the planning of communication activities in pharmaceutical companies in Jordan. The general framework of Balanced Scorecard consists of four dimensions: the financial perspective, the customers' perspective, the internal processes perspective and learning and growth perspective. The theoretical philosophy suggests that there is a balance and consistency in impacting of the four dimensions on the planning of marketing communication activities in the surveyed companies, and each perspective depends on others. Enhancing the impact of perspectives based on the strategic importance of the planning process. However, the research results show that the financial perspective applied by Jordanian pharmaceutical companies is very effective tool in planning of marketing communication activities and it has substitute role of the other non-financial measures (customers' perspective, internal processes perspective, and learning and growth perspective). However, it is important to note that, in certain cases on the long run, it may be difficult to convert some financial measures into intra-company procedures and using of the financial measures may not be the best solution to compensate lacking of the non-financial indicators, so the financial failure will be achieved. At the strategic level, it is necessary of making the equilibrium among BCS perspectives, because of the reliance on financial perspectives only, may be misleading and misunderstanding how to behave, and the relationship between communication objectives of the organization and planning of the marketing communication strategy will be rigor. In light of above, it may be difficult to choose the appropriate tools of communication mix for the market target, the size of organization, and the life cycle of organization as well. The interrelationships between the BCS perspectives are useful tools in planning of the marketing communication activities, and reinforcing the organizational performance of business firm at all. The BSC has communicative advantages fit the communicative objectives of business firms.

\section{References}

Abdalkrim, G. M. (2013), "The impact of strategic planning activities on private sector organizations performance in Sudan" An empirical research", International Journal of Business and Management, 8(10), 134.

Abhijit B. (2012), “Science Communication through Mass Media”, Res. J. Recent Sci., 1(1)

Adhiambo, N. (2014), "Balanced Scorecard \& Performance": A Case Study of Co -Operative Bank of Kenya. A Research Project Report Submitted In Partial Fulfillment of the Requirement for the Award of Masters of Business Administration, School of Business, University of Nairobi, 1-4.

Alao, E. (2013), "Strategic Decision Making, Balanced Scorecard Profitability: Issues and Challenges", International Journal of Accounting Research, 1(1), 20-31.

Amaratunga, D., Baldry, D., and Sarshar, M. (2001), "Process improvement through performance measurement: The balanced scorecard methodology", Work Study, 50(5), 179-88.

Amman Chamber of Industry, 2017. Annual Report. Amman.

Atkinson, A. and Epstein, M. (2000), "Measure for measure: realizing the power of the balanced scorecard", CMA Management, September, $8-23$.

Banerjee N., Siddhanta S. and Bandopadhyay G. (2012), The effect of marketing communication on sales performance: A study on the personal care industry in India”, European Journal of Social Sciences, 28(3).

Belch, G., and Belch, M. (2003), "Advertising and promotion: An integrated marketing perspective”, $6^{\text {th }}$ edition , London: The MCGraw-Hill Companies.

Bourne, M. (2002), “The emperor's new scorecard financial world”, August 20, 48-51.

Bourne, M., Neely, N., Platts, K. and Mills, J. (2000), "The success and failure of performance measurement initiatives: perceptions from participating managers", International Journal of Operations \& Production Management, 22 (11), 1288-310.

Braam, G. J. M., \& Nissen, E. J. (2004), "Performance effects of using the Balanced Scorecard: a note on the Dutch experience", Long Range Planning, 37, 355-349.

Bremser, W. G., and Barsky, N. P. (2004), "Utilizing the balanced scorecard for R\&D performance measurement" , R\&D Management, 34(3), 229-238. 
Bulter ,A. et al. (1997), "Linking the balanced score card to strategy", long range planning, 30(2) , 242-153.

Caune, J., and Dzedons, A. (2009), "Stratēăiskā vadīšana. Riga : Lidojošā zivs”, ISBN 978-9984-39-781-8.

Certo, Samuel et al. (1995), "The strategic management process", $3^{\text {rd }}$ Edition, Austen Press, Irwin, Chicago .

Chaudron, D. (2003), "The balanced scorecard \& performance improvement": retrieved from http://www.organisedchange.com/balancedscorecard.htm.

Chelliah,S., and Kwon, C. (2011), "A study of the relationship between marketing mix and customer retention for herbal coffee in Malaysia". ICBER.

Christesen, D. A. (2008), “ The impact of balanced scorecard usage on organization performance”. ProQuest.

Chytas, P. et al. (2011), “A proactive balanced scorecard”, International Journal of Information Management , 460 - 468.

Costa , C. (2015), "What is innovation in marketing communications today? " ESIC Business School.

Crabtree, A. D., \& DeBusk, G. K. (2008), “The effects of adopting the balanced scorecard on shareholder returns", Advances in Accounting , $24(1), 8-15$.

Cundall, D. (2018), “An introduction to strategic planning “, MNP Consulting .

Davis S. and Albright T. (2004), "An investigation of the effect of balanced scorecard implementation on financial performance" Management Accounting Research, 15, pp.135-153.

del Sordo, C., Orelli, R. L., Padovani, E., \& Gardini, S. (2012), “Assessing global performance in universities: an application of balanced scorecard", Procedia-Social and Behavioral Sciences, 46, 4793-4797.

Duncan, T., and Caywood, C. (1996), “The concept, process, and evolution of integrated marketing communication. In E”, Thorson and J. Moore (Eds.), Integrated communication: Synergy of persuasive voices. Mahwah, N.J . : Lawrence Erlbaum Associates.

Duncan, T., Moriarty, S. (1998), “A communication based marketing model for managing relationships”, Journal of Marketing, 62.

Fazli1, S., MafiYeganeh, A., and HashemiSiavoshani, A. ( 2013), "Implementation balanced scorecard in organizational performance : Case Study: Saipa company", International Research Journal of Applied and Basic Sciences, 6(3), 339-344.

Finley, P. (1999). Stategic Management . Harlow : Pearson Education Limited. ISBN 0- 201-39827-3.

Fisher, R., Maltz, E., and Jaworski, B. (1997), "Enhancing Communication between Marketing and Engineering: The Moderating Role of Relative Functional Identification", Journal of Marketing, 61(3).

Fleisher, C., and Bensoussan, B. (2002), "Strategic and Competitive Analysis: Methods and techniques for analyzing business competition" . Prentice Hall.

Franco, M. and Bourne, M. (2003), "Factors that play a role in managing through measures", Management Decision, 41,698-710.

Ghassan, F. A. (2011), "Performance Evaluation and Adoption of Balanced Scorecard (BSC) in Jordanian Industrial Companies", European Journal of Economics, Finance and Administrative Science, 35, 37-46.

Hoque, Z. (2014), "20 years of studies on the balanced scorecard: trends, accomplishments, gaps and opportunities for future research", The British Accounting Review, 46(1), 33-59.

Hoque, Z., James, W. (2000), "Linking balanced scorecard measures to size and market factors: Impact on Organizational Performance", Journal of Management Accounting Research, 12, 1-17.

Hua, N., and Lee, S. (2014), "Benchmarking firm capabilities for sustained financial performance in the US restaurant industry", International Journal of Hospitality Management, 36, 137-144.

Idres, H., Hamzah, D., Sudirman, I., and Hamid, N.(2017), "The Relevance of Financial and Non-Financial Compensation on Professionalism and Lecturers Performance: Evidence from Makassar Private Universities (Indonesia)" , Journal of Asian Development, $3(2), 162-180$.

Johnson, G, Scholes, K. Whittington, R. (2008), "Exploring Corporate Strategy”, 8th ed. FT Prentice Hall, 11-12

Kairu, E. W., Wafula, M. O., Okaka, O., Odera, O., \& Akerele, E. K. (2013), "Effects of balanced scorecard on performance of firms in the service sector", European Journal of Business and Management, 5(9), 81-88.

Kanibira, H., Saydanb, R., and Nartc, S. (2014), "Determining the Antecedents of Marketing Competencies of SMEs for International Market Performance", 10th International Strategic Management Conference, Procedia - Social and Behavioral Sciences, $150,12-23$.

Kanji, G.K. and Sa, P.M. (2002), “Kanji’s business scorecard “, Total Quality Management, 13(1), 13- 27.

Kaplan, R. S., and Norton, D. P. (1996), “The Balanced Scorecard: Translating Strategy into Action” , Harvard Business School Press, Cambridge, MA. 
Kaplan RS., Norton DP. (1992), "The Balance Scorecard: Measures that drive Performance”, Harvard Business Review, January- February, 71-9.

Kaplan RS., Norton, DP. (2004), "Strategy Maps: Converting Intangible Assets into Tangible Outcomes”, Harvard Business School Press.

Kaplan, R. S. (2001), "Strategic performance measurement and management in non-profit organizations" , Nonprofit Management and Leadership, 11(3), 353-370.

Kaplan, R. S. (2010), “Conceptual Foundation of the Balanced Scorecard”, Harvard Business School, Working Paper, $10-74$.

Kaplan, R. S., and Norton, D. P. (1996), "Using the Balances Scorecard as a Strategic Management System" , Harvard Business Review, January-February, 75-85.

Kaplan, R., \& Norton, D. P. (2015), "Balanced Scorecard Success: The Kaplan-Norton Collection (4 Books) “ Harvard Business Review Press. Retrieved from https://books.google.com/books?

Keller, K. (2009), "Building strong brands in a modern marketing communications Environment", Journal of Marketing Communications, $15(2-3)$.

Khan, M. W. J., Khalique, M., and Nor, R. M. (2014), "Exploring the Measurements of Organizational Performance" , Market Forces , college of management sciences, IX (2), 31-38.

Kitchen, P., and Schultz, D. (2003), "Integrated corporate and product brand communication. Advances in Competitiveness Research", 11 (1), 66-86.

Kotler, P., and Armstrong, G. (1997), “Principle of Marketing”,Prentice Hall International. NJ: Englewood Cliffs.

Kotler, P., and Keller, K. (2006), “Marketing Management”, 12 edition, . New Jersey: Prentice-Hall.

Kotler, P., and Keller, K. (2007), "Marketing Management, 12 edition, New Jersey: Pearson Education, Inc.

Krishnamurthy, S. (2000), "Enlarging the Pie Vs. Increasing One's Slice: An Analysis of the Relationship Between Generic and Brand Advertising', Marketing Letters, 11(1), 37-48.

Leiks, N. (2007), “Stratēăiskā plānošana”, Riga : Multineo . ISBN 978-9984-9957-0-1.

Lerkjarijumpon, N. (2015), “Applying Integrated Marketing Communication in Thai Marketing” , Review of Integrative Business and Economics Research, 4(4), 349-357.

Low, G. (2000), “Correlates of Integrated Marketing Communications”, Journal of Advertising Research, 40(3), 27-39.

Maleka , S. (2014), “Management and Strategic Planning Process”, South African Perspective, Conference: DTPS Strategic Planning \& Monitoring, At Pretoria, 1 .

Malina, M. A., Nørreklit, H. S. O., and Selto, F. H. (2007), “ Relations among measures, climate of control, and performance measurement models", Contemporary Accounting Research, 24(3), 935-982. www.ccsenet.org/ibr International Business Research , 6(10), 2013.

Marete, J. (2015), “ Influence of Balanced Scorecard on Organizational Performance in Institutions of Higher Learning: A Case Study of University of Nairobi and Centre for Mathematics, Science and Technology Education in Africa" , European Journal of Business and Management, 7(20), 106-116.

Maselli, J. ( 2002), “Better Communication Leads to More Sales”, Information Week, 889.

Mintzberg, H. (2004), “Managers, not MBAs: a hard look at the soft practice of managing and management development” , Berrett-Koehler, 464.

Mulhern, F.( 2009), “ Integrated Marketing Communications: From Media Channels to Digital Connectivity” , Journal of Marketing Communications, 15(2), 85-101.

Najjar, S. M., and Kalaf, K. H. (2012), “Designing a Balanced Scorecard to Measure a Bank’s Performance: A Case Study.” , International Journal of Business Administration, (3)4, 44-50.

Najjari,R., Jahanikia, A., Ahangar, N., and Yousefi, V. (2015), “ An Investigation on the Effect of Balanced Scorecard on Employees' Performances in Social Security Organization”, European Online Journal of Natural and Social Sciences , 4(1), 110-115.

Niven, P. R. (2003), “Balanced scorecard: Step-by-step for government and non-profit agencies”, Hoboken, NJ: John Wiley \& Sons, Inc.

Nowak, G., and Phelps, J. (1994), “Conceptualizing the integrated marketing communications’ phenomenon: an examination of its impact on advertising practices and its implications for advertising”, research. Journal of Current Issues and Research in Advertising, $16(1), 49-66$.

Odunlami I., and Ofoegbu O. (2011), “Effect of Marketing Communication In Promoting Organizational Sales. A Case Study of Sunshine Company”, Journal of Emerging Trends In Economics and Management Sciences,2(5).

Ondieki, E. (2017), “ The Effect of The Balanced Scorecard on Organizational Performance in The Public Sector in Kenya: A Case of Kenya 
Bureau of Standards", Research Project Report Submitted to the Chandaria, School of Business in Partial Fulfillment of the Requirement for the Degree of Master of Business Administration (MBA).

Rothaermel, F. T. (2012), “ Strategic. Management: Concepts and Cases”, McGraw-Hill/Irwin,5.

Saeed , R., Naeem, B., Bilal , M., and Naz, O. (2013), “Integrated Marketing Communication: A Review Paper. Interdisciplinary”, Journal of Contemporary Research In Business, 5(5).124.

Sahiti, A., Ahmeti, S., Sahiti, A., Aliu, M. (2016), “ The Impact of Balanced Scorecard on Improving the Performance and Profitability of the Implementing Companies", Mediterranean Journal of Social Sciences, 7(4), 50-65.

Sekran, U., and Bougie, R. (2016), "Research methods for business : A skill building approach ", $7^{\text {th }}$ edition. WILY. 243.

singh, P. K., \& Pattanayak, J. (2014), “Linking of Customer Satisfaction with Shareholders' value: A Review” , Global Journal of Finance and Management, 6(5), 403-412.

Sohani, N., and Singh, R. (2014) , “Enhancing Organizational Performance through Balance Scorecard with Strategic Management Activities", International Journal of Core Engineering \& Management (IJCEM), 1(1), 19-23

Sureshchandar, G.S., Rajendran, C. and Anantharaman, R.N. (2002), “ A holistic model for total quality service”, International Journal of Service Industry Management, 12(4), 378-412.

Tayles, M., Bramley, A., Adshead, N and Farr, J. (2002), "Dealing with the Management of Intellectual Capital: The potential role of Strategic Management Accounting”, Accounting, Auditing and Accountability Journal, 15(2), 251-267.

Vander, Z., and DE Jong J.T M. (1999), “Alignment is not Enough : Integrating Business \& Information Technology Management With The Balanced Score", Journal of Management Information Systems, 16(2).199.

Wangari, M. B., Anyango, D. M. O., and Wanjau, K. (2012), "Factors affecting provision of service quality in the public health sector: A case of Kenyatta national hospital” International Journal of Humanities and Social Science, 2 (13), 114-125.

Wasatorn, S. (2012), “ Balance score card practices and determination in Thailand “, Global Conference on Business and Financial Proceedings, 7 (1).

Wongrassam G.ardiner PD, and Simmons JEL. (2003), “ Performance Measurement Tools: The Balanced Scorecard and the EFQM Excellence Model”, Journal: Measuring Business Excellence, 7 (1), 14-28.

Okyere, N., Agyapong, G.., and Nyarku, K. (2011), "The Effect of Marketing Communications on the Sales Performance of Ghana Telecom (Vodafone, Ghana) “, International Journal of Marketing Studies, 3(4), 50-62.

Zairi, M., and Jarrar. Y.F. (2000), "Internal transfer of best practice for performance excellence: a global survey, Benchmarking “ , International Journal, 7 (4), 239-246. 